\title{
Virgibacillus soli sp. nov., isolated from mountain soil
}

\author{
P. Kämpfer, ${ }^{1}$ A. B. Arun, ${ }^{2}$ H.-J. Busse, ${ }^{3}$ S. Langer, ${ }^{3}$ C.-C. Young, ${ }^{4}$ \\ W.-M. Chen, ${ }^{5}$ A. A. Syed ${ }^{2}$ and P. D. Rekha ${ }^{2}$
}

\begin{abstract}
Correspondence
Peter Kämpfer peter.kaempfer@umwelt.unigiessen.de
\end{abstract}

\author{
${ }^{1}$ Institut für Angewandte Mikrobiologie, Justus-Liebig-Universität Giessen, D-35392 Giessen, \\ Germany \\ ${ }^{2}$ Yenepoya Research Centre, Yenepoya University, University Rd, Deralakatee, Mangalore, \\ Karnataka State, India \\ ${ }^{3}$ Institut für Bakteriologie, Mykologie und Hygiene, Veterinärmedizinische Universität, A-1210 Wien, \\ Austria \\ ${ }^{4}$ College of Agriculture and Natural Resources, Department of Soil \& Environmental Sciences, \\ National Chung Hsing University, Taichung, 402, Taiwan, ROC \\ ${ }^{5}$ Laboratory of Microbiology, Department of Seafood Science, National Kaohsiung Marine \\ University, Kaohsiung, Taiwan, ROC
}

\begin{abstract}
A Gram-positive bacterium (strain $\mathrm{CC}-\mathrm{YMP}-6^{\mathrm{T}}$ ) was isolated from soil samples collected from Yang-Ming Mountain, Taiwan. On the basis of 16S rRNA gene sequence analysis, strain CC-YMP $-6^{\top}$ clearly belonged to the genus Virgibacillus and was most closely related to the type strains of Virgibacillus halophilus (96.2\% similarity) and Virgibacillus kekensis (96.3\%). The predominant isoprenoid quinone was menaquinone MK-7 and the polar lipid profile was composed of the major components diphosphatidylglycerol, phosphatidylglycerol, phosphatidylethanolamine and one unidentified phospholipid plus moderate amounts of two unidentified aminophospholipids and a phospholipid. The polyamine pattern comprised spermidine as the single major component with spermine and putrescine present in minor amounts. The major fatty acids of strain CC-YMP- $6^{\top}$ were iso $-C_{15: 0}$ and anteiso- $C_{15: 0}$. The results of physiological and biochemical tests allowed the clear phenotypic differentiation of strain CC-YMP- $6^{\top}$ from all recognized species of the genus Virgibacillus. Strain CC-YMP-6 ${ }^{\top}$ is therefore considered to represent a novel species of the genus Virgibacillus, for which the name Virgibacillus soli sp. nov. is proposed. The type strain is CC-YMP-6 ${ }^{\top}$ (=DSM $22952^{\top}=\mathrm{CCM}^{-}$ $7714^{\mathrm{T}}$ ).
\end{abstract}

The genus Virgibacillus was proposed by Heyndrickx et al. (1998) to accommodate endospore-forming organisms previously assigned to Bacillus pantothenticus. At the time of writing, the genus comprised 20 recognized species, namely $V$. pantothenticus (Heyndrickx et al., 1998), $V$. proomii (Heyndrickx et al., 1999), V. carmonensis, $V$. marismortui, V. necropolis, V. picturae and $V$. salexigens (Heyrman et al., 2003), V. halodenitrificans (Yoon et al., 2004), V. dokdonensis (Yoon et al., 2005), V. koreensis (Lee et al., 2006), V. halophilus (An et al., 2007), V. olivae (Quesada et al., 2007), V. salarius (Hua et al., 2008), V. chiguensis (Wang et al., 2008), V. kekensis (Chen et al., 2008), V. salarius (Hua et al. 2008), V. salinus (Carrasco

The GenBank/EMBL/DDBJ accession number for the 16S rRNA gene sequence of strain CC-YMP-6 ${ }^{\top}$ is EU213011.

Supplementary figures are available with the online version of this paper. et al., 2009), V. sedimenti (Chen et al., 2009), V. arcticus (Niederberger et al., 2009) and V. byusanensis (Yoon et al., 2010).

Strain CC-YMP- $6^{\mathrm{T}}$ was isolated from soil samples collected from Yang-Ming Mountain (Taiwan) on nutrient agar (NA; Oxoid). The isolate was maintained on NA after incubation at $30{ }^{\circ} \mathrm{C}$ for $48 \mathrm{~h}$, and was preserved at $-80{ }^{\circ} \mathrm{C}$ in nutrient broth (NB; Oxoid) with $20 \%(\mathrm{v} / \mathrm{v})$ glycerol or by lyophilization. Orange to brownish colonies with a diameter of 2-4 mm were observed after 3 days of incubation on Caso agar (Merck 105458). Morphological properties and Gram-staining were investigated by phasecontrast microscopy as described previously (Kämpfer et al., 2009, 2010). Strain CC-YMP-6 ${ }^{\mathrm{T}}$ formed highly motile rod-shaped cells of about $0.5 \times 5 \mu \mathrm{m}$ (some longer cells were observed). A Gram-positive to Gram-variable reaction was observed after incubation for $24 \mathrm{~h}$ at $28{ }^{\circ} \mathrm{C}$ in 
NB. Endospore formation was observed after 3 days of cultivation at $30{ }^{\circ} \mathrm{C}$ on Caso agar supplemented with $10 \mathrm{mg} \mathrm{MnSO}_{4} \cdot \mathrm{H}_{2} \mathrm{O}$. Strain CC-YMP-6 ${ }^{\mathrm{T}}$ produced spherical to ellipsoidal spores in a terminal position (see Supplementary Fig. S1 in IJSEM Online). Extracellular deposits were observed (Supplementary Fig. S1), but no parasporal bodies. Anaerobic growth was detected in tryptone soy broth in tubes with an overlay of paraffin oil after 3 days of incubation.

Isolation of DNA was performed by using the commercial DNA extraction kit (GenElute Plant Genomic DNA kit; Sigma). The $16 \mathrm{~S}$ rRNA gene was analysed as described previously (Kämpfer et al., 2003). Multiple sequence alignment and analysis of the data were performed with the MEGA software package, version 4 (Tamura et al. 2007), as well as with the ARB software package (version of December 2007; Ludwig et al., 2004) and the corresponding SILVA SSURef 95 database (release of July 2008; Pruesse et al., 2007). Genetic distances were calculated (distance options according to the Kimura two-parameter model) and clustering was performed with the neighbourjoining method and the maximum-parsimony method (results not shown) by using MEGA version 4 , and bootstrap values based on 1000 replications. Tree reconstruction via the maximum-likelihood method with fastDNAml (Olsen et al., 1994) and a $30 \%$ conservatory filter (only alignment columns in which the frequency of the most abundant nucleotide is equal to or above $30 \%$ are included in the calculation) was performed with the ARB software package (Fig. 1). Tree topology was further tested without filters. No differences were detected between these trees.

The $16 \mathrm{~S}$ rRNA gene sequence of strain CC-YMP- $6^{\mathrm{T}}$ was a continuous stretch of $1526 \mathrm{bp}$. Sequence similarity calculations showed that the closest relatives of strain CC-YMP- $6^{\mathrm{T}}$ were V. halophilus $5 \mathrm{~B} 73 \mathrm{C}^{\mathrm{T}}(96.2 \%)$ and V. kekensis YIM kkny16 ${ }^{\mathrm{T}}(96.3 \%)$.

For polyamine, quinone and polar lipid analyses, cells were grown in PYE medium $(0.3 \%$ peptone from casein, $0.3 \%$ yeast extract, $\mathrm{pH} 7.2)$ at $28{ }^{\circ} \mathrm{C}$. Analyses were carried out as described by Busse \& Auling (1988), Altenburger et al. $(1996,1997)$ and Tindall (1990a, b). HPLC analyses of the quinone system and polyamines were performed by using the instruments described by Stolz et al. (2007). The polyamine pattern consisted of (per g dry weight) $3.2 \mu \mathrm{mol}$ spermidine, $0.1 \mu \mathrm{mol}$ spermine and $0.03 \mu \mathrm{mol}$ putrescine. Similar polyamine patterns have been reported for other mesophilic bacilli in the genera Bacillus, Paenibacillus, Brevibacillus and Aneurinibacillus. Thermophilic bacilli such as species of the genera Geobacillus and Alicyclobacillus have spermine as the major polyamine (Hamana et al., 1989, 1993; Meier-Stauffer et al., 1996). The quinone system of strain CC-YMP- $6^{\mathrm{T}}$ was composed of menaquinone

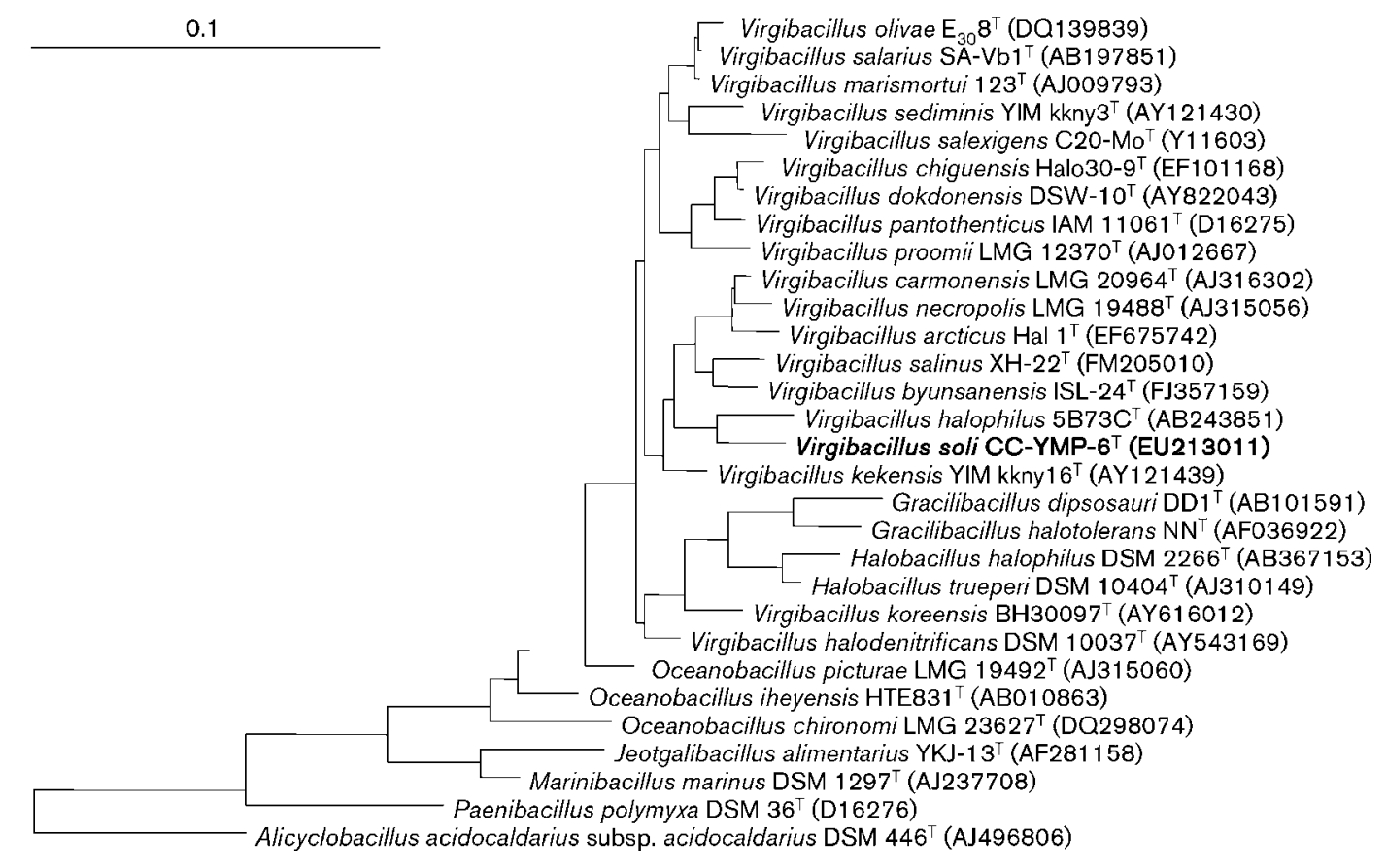

Fig. 1. Phylogenetic analysis based on $16 \mathrm{~S}$ rRNA gene sequences showing the position of strain CC-YMP- $6^{\top}$ among its closest relatives (available from the EMBL database; accession numbers in parentheses). The phylogenetic tree was constructed by using the ARB software package (version of December 2007; Ludwig et al., 2004) and the corresponding SILVA SSURef 95 database (release of July 2008; Pruesse et al., 2007). Tree building was performed by using the maximumlikelihood method with fastDNAml (Olsen et al., 1994). For better clarity, only a subset of the sequences used for treeing is shown. Bar, 0.1 nt substitutions per nucleotide position. 
MK-7 (93\%) and MK-6 (7\%). In the polar lipid profile (see Supplementary Fig. S2), the major components were diphosphatidylglycerol, phosphatidylglycerol, phosphatidylethanolamine and one unidentified phospholipid (PL1). Moderate amounts of two unidentified aminophospholipids (APL1, APL2) and one phospholipid (PL2) and traces of an unidentified phospholipid (PL3), an aminolipid, a third aminophospholipid (APL3) and two lipids (L1, L2), not stainable with any of the applied specific spray reagents, were found. The three aminophospholipids showed a highly hydrophilic chromatographic behaviour. The presence of phosphatidylethanolamine has been reported for several species of the genus Virgibacillus, including V. pantothenicus, but not for others (e.g. V. carmonensis) and only as a trace component in $V$. salexigens (Wainø et al., 1999; Heyrman et al., 2003). On the other hand, two phospholipids with a chromatographic behaviour similar to PL1 and PL2 (Supplementary Fig. S2) were reported for $V$. salexigens, but not for $V$. pantothenticus. However, this polar lipid profile supported the assignment of strain CC-YMP-6 ${ }^{\mathrm{T}}$ to the genus Virgibacillus.

Fatty acid analysis was performed according to Kämpfer \& Kroppenstedt (1996). The fatty acid profile of strain CCYMP- $6^{\mathrm{T}}$ was similar to those of recognized species of the genus Virgibacillus, and closely matched those of $V$. kekensis and V. halophilus (Table 1).
Results of comparative physiological characterization are given in the species description below and in Table 2, with methods as described previously (Kämpfer et al., 1991, 2009). The observed differences in fatty acid profiles and physiological test results together with the phylogenetic data presented suggest that strain CC-YMP- $6^{\mathrm{T}}$ represents a novel species of the genus Virgibacillus, for which the name Virgibacillus soli sp. nov. is proposed.

\section{Description of Virgibacillus soli sp. nov.}

Virgibacillus soli (so'li. L. neut. gen. n. soli of soil, the source of the type strain).

Cells are Gram-positive to Gram-variable rods, about $0.5 \times 5 \mu \mathrm{m}$ (some longer cells may occur), showing facultatively anaerobic respiratory metabolism, but not denitrification. Endospores are spherical to ellipsoidal in a terminal position. Extracellular deposits are detected but not parasporal bodies. Good growth occurs after 3 days of incubation on NA at $25-30{ }^{\circ} \mathrm{C}$, and also on tryptone soy agar. Moderate growth occurs after 3-7 days of incubation in NB under anaerobic conditions. On both agar media, orange to brownish colonies are produced. Optimal temperature for growth is $25-30{ }^{\circ} \mathrm{C}$; growth occurs at $15-40{ }^{\circ} \mathrm{C}$, but not at 5 or $45{ }^{\circ} \mathrm{C}$. Optimal pH for growth is $7.5-8.5$; growth occurs at

Table 1. Whole-cell fatty acid profiles of strain CC-YMP-6 ${ }^{\top}$ and related species of the genus Virgibacillus

Strains: 1, CC-YMP-6 ${ }^{\mathrm{T}}$ (data from the present study); 2, V. kekensis YIM kkny16 ${ }^{\mathrm{T}} ; 3$, V. halophilus $\mathrm{KCTC}_{13935^{\mathrm{T}}}$ (An et al., 2007); 4, V marismortui KCTC $3845^{\mathrm{T}}$; 5, V. halodenitrificans KCTC $3790^{\mathrm{T}} ; 6$, V. olivae DSM $18098^{\mathrm{T}}$ (Quesada et al., 2007); 7, V. carmonensis KCTC $3819^{\mathrm{T}}$; 8, V. proomii KCTC $3822^{\mathrm{T}}$; 9, V. pantothenticus KCTC $3539^{\mathrm{T}}$; 10, V. dokdonensis KCTC $3933^{\mathrm{T}}$ (An et al., 2007); 11, V. necropolis KCTC $3820^{\mathrm{T}}$; 12, V. salexigens KCTC $3844^{\mathrm{T}} ; 13$, V. koreensis KCTC $3823^{\mathrm{T}}$. Other reference data are from Lee et al. (2006). The fatty acid profiles of V. halophilus DSM $12325^{\mathrm{T}}$ and V. kekensis DSM $10037^{\mathrm{T}}$ were confirmed in parallel tests with strain CC-YMP- $6^{\mathrm{T}}$ under identical conditions. Data are percentages of the total fatty acids; components representing $<1.0 \%$ of the total are not shown.

\begin{tabular}{|c|c|c|c|c|c|c|c|c|c|c|c|c|c|}
\hline Fatty acid & 1 & 2 & 3 & 4 & 5 & 6 & 7 & 8 & 9 & 10 & 11 & 12 & 13 \\
\hline $\mathrm{C}_{14: 0}$ & 8.4 & 1.7 & 2.1 & & & 1.3 & & & & 2.1 & & & 1.8 \\
\hline $\mathrm{C}_{15: 0}$ & & & 1.4 & & & 1.1 & & & & & & & 5.1 \\
\hline $\mathrm{C}_{18: 0}$ & & 2.1 & & & & 1.2 & & & & & & & \\
\hline $\mathrm{C}_{16: 1} \omega 7 c$ alcohol & 1.2 & 8.1 & & 1.1 & 3.1 & 1.3 & 6.5 & & & & 2.4 & & 3.4 \\
\hline $\mathrm{C}_{16: 1} \omega 11 c$ & 3.3 & & & & & 1.7 & & & & & 1.0 & & 2.2 \\
\hline iso- $\mathrm{C}_{13: 0}$ & 2.1 & & & & & & & & & 1.0 & & & \\
\hline anteiso- $\mathrm{C}_{13: 0}$ & 1.2 & & & & & & & & & 1.8 & & & \\
\hline iso- $\mathrm{C}_{14: 0}$ & 6.4 & 13.3 & 5.6 & 2.9 & 7.4 & 2.1 & 3.3 & 2.4 & 2.3 & 2.1 & 2.2 & 4.2 & 8.3 \\
\hline iso- $\mathrm{C}_{15: 0}$ & 37.0 & 2.6 & 21.2 & 39.0 & 2.4 & 33.7 & 5.7 & 15.1 & 7.1 & 15.5 & 3.8 & 34.0 & 6.1 \\
\hline anteiso- $\mathrm{C}_{15: 0}$ & 28.2 & 50.4 & 35.8 & 33.9 & 51.8 & 28.4 & 58.29 & 38.5 & 55.3 & 47.0 & 67.9 & 30.5 & 43.4 \\
\hline iso- $\mathrm{C}_{16: 0}$ & 2.0 & 6.1 & 10.3 & 4.3 & 11.8 & 3.9 & 6.4 & 7.3 & 7.2 & 3.7 & 4.2 & 8.4 & 14.4 \\
\hline 4 & & & & & 1.6 & & & & & & & & \\
\hline
\end{tabular}

*Summed features are groups of two or threee fatty acids that could not be separated by GC using the MIDI system: summed feature 3 contained $\mathrm{C}_{16: 1} \omega 7 c$ and/or iso- $\mathrm{C}_{15: 0} 2-\mathrm{OH}$; summed feature 4 contained iso- $\mathrm{C}_{15: 0} 2-\mathrm{OH}$ and/or $\mathrm{C}_{16: 1} \omega 7 t$. 
Table 2. Differential characteristics between strain CC-YMP- $6^{\top}$ and related species of the genus Virgibacillus

Taxa: 1, strain CC-YMP-6 ${ }^{\mathrm{T}}$; 2, V. kekensis YIM kkny16 ${ }^{\mathrm{T}}$; 3, V. halophilus (An et al., 2007); 4, V. marismortui (Arahal et al., 1999, 2000; Heyrman et al., 2003); 5, V. halodenitrificans (Yoon et al., 2004); 6, V. olivae (Quesada et al., 2007); 7, V. carmonensis (Heyrman et al., 2003); 8, V. proomii (Heyndrickx et al., 1999; Heyrman et al. 2003); 9, V. pantothenicus (Heyndrickx et al., 1999; Heyrman et al. 2003); 10, V. dokdonensis (Yoon et al., 2005); 11, V. necropolis (Heyrman et al. 2003); 12, V. salexigens (Garabito et al., 1997; Wainø et al., 1999; Heyrman et al., 2003); 13, V. koreensis (Lee et al., 2006). +, Positive; -, negative; v, variable; w, weakly positive; pr, predominant; tr, trace; ND, no data available. Data in parentheses are for the type strain.

\begin{tabular}{|c|c|c|c|c|c|c|c|c|c|c|c|c|c|}
\hline Characteristic & 1 & 2 & 3 & 4 & 5 & 6 & 7 & 8 & 9 & 10 & 11 & 12 & 13 \\
\hline Spore shape $e^{*}$ & $E, S$ & $\mathrm{E}, \mathrm{S}$ & $\mathrm{E}$ & $\mathrm{E}$ & $\mathrm{E}$ & $S, E$ & $\mathrm{E}, \mathrm{S}$ & S, E & S, E & $S, E$ & $\mathrm{E}$ & $\mathrm{E}$ & E \\
\hline Spore position $\dagger$ & $\mathrm{T}$ & $\mathrm{T}$ & ST & $\mathrm{T}, \mathrm{ST}$ & $\mathrm{T}, \mathrm{ST}$ & $\mathrm{T}, \mathrm{ST}$ & ST & $\mathrm{T}, \mathrm{ST}$ & $\mathrm{T}, \mathrm{ST}$ & $\mathrm{T}, \mathrm{ST}$ & C, ST, T & $\mathrm{C}, \mathrm{ST}, \mathrm{T}$ & $\mathrm{T}$ \\
\hline Anaerobic growth & + & - & - & - & + & - & - & + & + & + & - & - & + \\
\hline Temperature range $\left({ }^{\circ} \mathrm{C}\right)$ & $15-40$ & $10-50$ & $5-45$ & $15-50$ & $10-45$ & $20-45$ & $10-40$ & $15-50$ & $15-50$ & $15-50$ & $10-40$ & $15-45$ & $10-45$ \\
\hline \multicolumn{14}{|l|}{ Growth in/at: } \\
\hline $0 \%(\mathrm{w} / \mathrm{v}) \mathrm{NaCl}$ & + & + & + & - & - & + & - & ND & ND & + & $\mathrm{w}$ & - & - \\
\hline $20 \%(\mathrm{w} / \mathrm{v}) \mathrm{NaCl}$ & - & + & - & - & + & $\mathrm{v}(+)$ & - & - & - & + & - & + & - \\
\hline $\mathrm{pH} 10$ & + & + & + & - & - & - & $\mathrm{ND}$ & - & - & $\mathrm{ND}$ & ND & + & - \\
\hline \multicolumn{14}{|l|}{ Hydrolysis of: $\ddagger$} \\
\hline Aesculin & - & - & ND & + & $\mathrm{v}(-)$ & $\mathrm{v}(+)$ & $\mathrm{w}$ & + & + & + & - & + & + \\
\hline Casein & - & - & ND & + & - & $\mathrm{v}(+)$ & + & + & + & + & + & + & $\mathrm{ND}$ \\
\hline Gelatin & + & - & ND & + & + & + & - & $\mathrm{v}$ & + & + & $\mathrm{w}$ & + & - \\
\hline Starch & + & + & $\mathrm{ND}$ & - & - & + & $\mathrm{ND}$ & ND & ND & + & ND & - & ND \\
\hline $\mathrm{H}_{2} \mathrm{~S}$ production $\ddagger$ & - & - & - & + & - & $\mathrm{ND}$ & - & - & $\mathrm{v}$ & - & - & + & - \\
\hline Nitrate reduction $\ddagger$ & + & + & + & + & + & + & + & - & $\mathrm{v}$ & - & + & - & - \\
\hline \multicolumn{14}{|l|}{ Acid production from: } \\
\hline$N$-Acetylglucosamine & - & - & + & + & + & $\mathrm{ND}$ & - & + & + & + & $\mathrm{w}$ & $\mathrm{w}$ & - \\
\hline D-Galactose & - & - & $\mathrm{w}$ & - & + & - & - & + & - & + & - & $\mathrm{w}$ & - \\
\hline D-Glucose & $\mathrm{w}$ & + & + & + & + & - & - & + & - & + & $\mathrm{w}$ & $\mathrm{w}$ & $\mathrm{w}$ \\
\hline D-Fructose & - & + & + & - & $\mathrm{v}(+)$ & + & - & + & - & + & $\mathrm{w}$ & $\mathrm{W}$ & + \\
\hline D-Mannitol & - & $\mathrm{w}$ & + & - & + & - & - & + & - & - & - & - & - \\
\hline D-Mannose & - & - & + & + & + & - & - & + & - & + & $\mathrm{w}$ & $\mathrm{w}$ & - \\
\hline Trehalose & - & $\mathrm{w}$ & + & - & + & $\mathrm{ND}$ & - & + & + & - & $\mathrm{w}$ & - & $\mathrm{w}$ \\
\hline \multicolumn{14}{|l|}{ Menaquinones (\%) } \\
\hline MK-6 & 7 & 6.1 & $\mathrm{ND}$ & 1.8 & 2.0 & ND & 2 & 1 & 1 & Minor & 2 & 2 & ND \\
\hline MK-7 & 93 & 93.2 & $\mathrm{pr}$ & 97.6 & 97.7 & $\mathrm{ND}$ & 98 & 99 & 98 & pr & 97 & 98 & pr \\
\hline MK-8 & ND & 0.7 & ND & 0.6 & 0.3 & $\mathrm{ND}$ & 1 & 1 & 1 & ND & $\operatorname{tr}$ & $\operatorname{tr}$ & ND \\
\hline
\end{tabular}

${ }^{\star}$ E, ellipsoidal; s, spherical.

†C, central; ST, subterminal; T, terminal.

¥Unless otherwise indicated, results of these tests for $V$. halophilus DSM $12325^{\mathrm{T}}$ and $V$. kekensis DSM $10037^{\mathrm{T}}$ were confirmed in parallel tests with strain CC-YMP- $6^{\mathrm{T}}$ under identical conditions.

$\mathrm{pH} 7.0-10.0 . \mathrm{NaCl}$ is not required for growth; tolerates up to $6 \%(\mathrm{w} / \mathrm{v}) \mathrm{NaCl}$. Catalase- and oxidase-positive. Gelatin and starch are hydrolysed. $\mathrm{H}_{2} \mathrm{~S}$, indole and acetoin are not produced. Nitrate is reduced to nitrite under aerobic conditions. Positive for gelatinase activity, but negative for urease, $\beta$-galactosidase, arginine dihydrolase, lysine decarboxylase, ornithine decarboxylase, tryptophan deaminase and citrate utilization. Acid production from different sugars is detailed in Table 2. Glucose and sucrose are utilized as sole source of carbon (weak results after 7 days of incubation). The quinone system comprises menaquinone MK-7 with minor amounts of MK-6. The polar lipid profile is composed of the major components diphosphatidylglycerol, phosphatidylglycerol, phosphatidylethanolamine and one unidentified phospholipid and moderate amounts of two unidentified aminophospholipids and one phospholipid. Trace amounts of two polar lipids, an aminolipid, a third aminophospholipid and a third phospholipid are detectable. The polyamine pattern consists of the major component spermidine; spermine and putrescine are present in minor amounts. The major fatty acids are iso- $\mathrm{C}_{15: 0}$ and anteiso- $\mathrm{C}_{15: 0}$.

The type strain, CC-YMP-6 ${ }^{\mathrm{T}} \quad\left(=\mathrm{DSM} \quad 22952^{\mathrm{T}}=\mathrm{CCM}\right.$ $7714^{\mathrm{T}}$ ), was isolated from soil samples collected from Yang-Ming Mountain, Taiwan.

\section{Acknowledgements}

We are grateful to Gundula Will for excellent technical assistance and Dr Rüdiger Pukall for providing Supplementary Fig. S1. 


\section{References}

Altenburger, P., Kämpfer, P., Makristathis, A., Lubitz, W. \& Busse, H.-J. (1996). Classification of bacteria isolated from a medieval wall painting. J Biotechnol 47, 39-52.

Altenburger, P., Kämpfer, P., Akimov, V. N., Lubitz, W. \& Busse, H.-J. (1997). Polyamine distribution in actinomycetes with group B peptidoglycan and species of the genera Brevibacterium, Corynebacterium and Tsukamurella. Int J Syst Bacteriol 47, 270-277.

An, S. Y., Asahara, M., Goto, K., Kasai, H. \& Yokota, A. (2007). Virgibacillus halophilus sp. nov., spore-forming bacteria isolated from soil in Japan. Int J Syst Evol Microbiol 57, 1607-1611.

Arahal, D. R., Márquez, M. C., Volcani, B. E., Schleifer, K. H. \& Ventosa, A. (1999). Bacillus marismortui sp. nov., a new moderately halophilic species from the Dead Sea. Int J Syst Bacteriol 49, 521-530.

Arahal, D. R., Márquez, M. C., Volcani, B. E., Schleifer, K. H. \& Ventosa, A. (2000). Reclassification of Bacillus marismortui as Salibacillus marismortui comb. nov. Int J Syst Evol Microbiol 50, 1501-1503.

Busse, H.-J. \& Auling, G. (1988). Polyamine pattern as a chemotaxonomic marker within the Proteobacteria. Syst Appl Microbiol 11, 1-8.

Carrasco, I. J., Márquez, C. M. \& Ventosa, A. (2009). Virgibacillus salinus sp. nov., a moderately halophilic bacterium from sediment of a saline lake. Int J Syst Evol Microbiol 59, 3068-3073.

Chen, Y. G., Cui, X. L., Fritze, D., Chai, L. H., Schumann, P., Wen, M. L., Wang, Y. X., Xu, L. H. \& Jiang, C. L. (2008). Virgibacillus kekensis sp. nov., a moderately halophilic bacterium isolated from a salt lake in China. Int J Syst Evol Microbiol 58, 647-653.

Chen, Y. G., Cui, X. L., Wang, Y. X., Zhang, Y. Q., Tang, S. K., Li, W. J., Liu, Z. X., Wen, M. L. \& Peng, O. (2009). Virgibacillus sediminis sp. nov., a moderately halophilic bacterium isolated from a salt lake in China. Int J Syst Evol Microbiol 59, 2058-2063.

Garabito, M. J., Arahal, D. R., Mellado, E., Márquez, M. C. \& Ventosa, A. (1997). Bacillus salexigens sp. nov., a new moderately halophilic Bacillus species. Int J Syst Bacteriol 47, 735-741.

Hamana, K., Akiba, T., Uchino, F. \& Matsuzaki, S. (1989). Distribution of spermine in bacilli and lactic bacteria. Can $J$ Microbiol 35, 450-455.

Hamana, K., Hamana, H., Niitsu, M., Samejima, K., Sakane, T. \& Yokota, A. (1993). Tertiary and quaternary branched polyamines distributed in thermophilic Saccharococcus and Bacillus. Microbios 75, 23-32.

Heyndrickx, M., Lebbe, L., Kersters, K., De Vos, P., Forsyth, G. \& Logan, N. A. (1998). Virgibacillus: a new genus to accommodate Bacillus pantothenticus (Proom and Knight 1950). Emended description of Virgibacillus pantothenticus. Int J Syst Bacteriol 48, 99-106.

Heyndrickx, M., Lebbe, L., Kersters, K., Hoste, B., De Wachter, R., De Vos, P., Forsyth, G. \& Logan, N. A. (1999). Proposal of Virgibacillus proomii sp. nov. and emended description of Virgibacillus pantothenticus (Proom and Knight 1950) Heyndrickx et al. 1998. Int J Syst Bacteriol, 49, 1083-1090.

Heyrman, J., Logan, N. A., Busse, H. J., Balcaen, A., Lebbe, L., Rodriguez-Diaz, M., Swings, J. \& De Vos, P. (2003). Virgibacillus carmonensis sp. nov., Virgibacillus necropolis sp. nov. and Virgibacillus picturae sp. nov., three novel species isolated from deteriorated mural paintings, transfer of the species of the genus Salibacillus to Virgibacillus, as Virgibacillus marismortui comb. nov. and Virgibacillus salexigens comb. nov., and emended description of the genus Virgibacillus. Int J Syst Evol Microbiol 53, 501-511.

Hua, N. P., Hamza-Chaffai, A., Vreeland, R. H., Isoda, H. \& Naganuma, T. (2008). Virgibacillus salarius sp. nov., a halophilic bacterium isolated from a Saharan salt lake. Int J Syst Evol Microbiol 58, 2409-2414.

Kämpfer, P. \& Kroppenstedt, R. M. (1996). Numerical analysis of fatty acid patterns of coryneform bacteria and related taxa. Can $J$ Microbiol 42, 989-1005.

Kämpfer, P., Steiof, M. \& Dott, W. (1991). Microbiological characterization of a fuel-oil contaminated site including numerical identification of heterotrophic water and soil bacteria. Microb Ecol 21, 227-251.

Kämpfer, P., Dreyer, U., Neef, A., Dott, W. \& Busse, H.-J. (2003). Chryseobacterium defluvii sp. nov., isolated from wastewater. Int J Syst Evol Microbiol 53, 93-97.

Kämpfer, P., Lodders, N., Warfolomeow, I. \& Busse, H.-J. (2009). Tessaracoccus lubricantis sp. nov. isolated from a metalworking fluid. Int J Syst Evol Microbiol 59, 1545-1549.

Kämpfer, P., Falsen, E., Lodders, N. \& Schumann, P. (2010). Sporosarcina contaminans sp. nov., and Sporosarcina thermotolerans sp. nov., two novel endospore-forming species. Int $J$ Syst Evol Microbiol 60 1353-1357.

Lee, J. S., Lim, J. M., Lee, K. C., Lee, J. C., Park, Y. H. \& Kim, C. J. (2006). Virgibacillus koreensis sp. nov., a novel bacterium from a salt field, and transfer of Virgibacillus picturae to the genus Oceanobacillus as Oceanobacillus picturae comb. nov. with emended descriptions. Int J Syst Evol Microbiol 56, 251-257.

Ludwig, W., Strunk, O., Westram, R., Richter, L., Meier, H., Yadhukumar, Buchner, A., Lai, T., Steppi, S. \& other authors (2004 ). ARB: a software environment for sequence data. Nucleic Acids Res 32, 1363-1371.

Meier-Stauffer, K., Busse, H.-J., Rainey, F. A., Burghardt, J., Scheberl, A., Hollaus, F., Kuen, B., Makristathis, A., Sleytr, U. B. \& Messner, P. (1996). Description of Bacillus thermoaerophilus sp. nov., to include sugar beet isolates and Bacillus brevis ATCC 12990. Int J Syst Bacteriol 46, 532-541.

Niederberger, T. D., Steven, B., Charvet, S., Barbier, B. \& White, L. G. (2009). Virgibacillus arcticus sp. nov., a moderately halophilic, endospore-forming bacterium from permafrost in the Canadian high Arctic. Int J Syst Evol Microbiol 59, 2219-2225.

Olsen, G. J., Matsuda, H., Hagstrom, R. \& Overbeek, R. (1994). fastDNAml: a tool for construction of phylogenetic trees of DNA sequences using maximum likelihood. Comput Appl Biosci 10, 41-48.

Pruesse, E., Quast, C., Knittel, K., Fuchs, B. M., Ludwig, W., Peplies, J. \& Glöckner, F. O. (2007). SILVA: a comprehensive online resource for quality checked and aligned ribosomal RNA sequence data compatible with ARB. Nucleic Acids Res 35, 7188-7196.

Quesada, T., Aguilera, M., Morillo, J. A., Ramos-Cormenzana, A. \& Monteoliva-Sánchez, M. (2007). Virgibacillus olivae sp. nov., isolated from waste wash-water from processing of Spanish-style green olives. Int J Syst Evol Microbiol 57, 906-910.

Stolz, A., Busse, H.-J. \& Kämpfer, P. (2007). Pseudomonas knackmussii sp. nov. Int J Syst Evol Microbiol 57, 572-576.

Tamura, K., Dudley, J., Nei, M. \& Kumar, S. (2007). MEGA4: Molecular evolutionary genetics analysis (MEGA) software version 4.0. Mol Biol Evol 24, 1596-1599.

Tindall, B. J. (1990a). Lipid composition of Halobacterium lacusprofundi. FEMS Microbiol Lett 66, 199-202.

Tindall, B. J. (1990b). A comparative study of the lipid composition of Halobacterium saccharovorum from various sources. Syst Appl Microbiol 13, 128-130.

Wainø, M., Tindall, B., Schumann, P. \& Ingvorsen, K. (1999). Gracilibacillus gen. nov., with description of Gracilibacillus halotolerans gen. nov., sp. nov.; transfer of Bacillus dipsosauri to Gracilibacillus 
dipsosauri comb. nov., and Bacillus salexigens to the genus Salibacillus gen. nov., as Salibacillus salexigens comb. nov. Int J Syst Bacteriol 49, 821-831.

Wang, C. Y., Chang, C. C., Ng, C. C., Chen, T. W. \& Shyu, Y. T. (2008). Virgibacillus chiguensis sp. nov., a novel halophilic bacterium isolated from Chigu, a previously commercial saltern located in southern Taiwan. Int J Syst Evol Microbiol 58, 341-345.

Yoon, J. H., Oh, T. K. \& Park, Y. H. (2004). Transfer of Bacillus halodenitrificans Denariaz et al. 1989 to the genus Virgibacillus as
Virgibacillus halodenitrificans comb. nov. Int J Syst Evol Microbiol 54, 2163-2167.

Yoon, J. H., Kang, S. J., Lee, S. Y., Lee, M. H. \& Oh, T. K. (2005), Virgibacillus dokdonensis sp. nov., isolated from a Korean island, Dokdo, located at the edge of the East Sea in Korea. Int J Syst Evol Microbiol 55, 1833-1837.

Yoon, J. H., Kang, S. J., Jung, Y. T., Lee, K. C., Oh, H. W. \& Oh, T. K. (2010). Virgibacillus byunsanensis sp. nov., isolated from a marine solar saltern. Int J Syst Evol Microbiol 60, 291-295. 